\title{
HBIM FROM A FIRST CENTURY ICONOGRAPHY
}

\author{
Sara Gonizzi Barsanti ${ }^{1}$, Santiago Lillo Giner ${ }^{2}$, Adriana Rossi ${ }^{1}$ \\ 1 Department of Engineering, Università degli Studi della Campania Luigi Vanvitelli, Aversa (CE), Italy \\ (sara.gonizzibarsanti, adriana.rossi)@unicampania.it
}

${ }^{2}$ Escuela Técnica Superior de Arquitectura, Universitat Politècnica de València, España, sanlilgi@ega.upv.es

\section{Commission II}

KEY WORDS: Cultural Heritage, Virtual Reconstruction, 3D Reconstruction, HBIM, Workflow, Data Sharing Environment

\begin{abstract}
:
Protecting and enhancing inherited assets is a duty of every age; ours requires disclosure through the services of the interconnected network, the only one, to date, capable of reaching a wide audience and with it attracting adequate economic resources for the implementation of programs. In keeping with the international definition of "Cultural Heritage", the paper describes the methodology that guided the construction in 3D of the monumental building sculpted in the iconographies between 52 and $62 \mathrm{AD}$ on the marble slab now preserved at the archaeological museum of Perugia. An informative workflow on what has been collected is proposed to then discuss the potential of its uses. The focus lies in particular on the possibility of the model to act as an interoperable collector to compare the reconstructive hypotheses.

The final objective looks at the opportunity to create multimedia, multimodal and cross modal collaboration spaces to remedy aspects that, by affecting a wider audience of users, encourage socio-economic policies.
\end{abstract}

\section{INTRODUCTION}

In step with the times and in line with the most recent guidelines for the Safeguarding of Cultural Heritage, the services offered by the network (internet) expand the potential and the cognitive dimensions: in fact, the accessibility benefits the learning by promoting actions that cross different sectors and areas (Bentkowska-kaFel, Denard, 2012). In this perspective, Digital Heritage (Hugh, 2012, p. 60) refers to an interdisciplinary approach and strategy, capable of involving and attracting the interest of a wider audience (Brusaporci, 2020). The London Charter for the virtual visualization of Cultural Heritage ${ }^{1}$ (2009) directs towards a good practice that the "Principles of Sevilla" (2012) channel into a shared process between the scientific communities (Denar, 2012).

Observing with a renewed spirit the slab of Perugia (1st century $\mathrm{AD}$ ), a document of fundamental interest for the history of relief and architectural design, therefore has a fourfold purpose:

- collect and order what has been examined on a cartographic practice already recurring to the death of Augustus;

- explain the pipeline used for the 3D reconstruction of the building starting from plans and measurements (Barratt, 2018, Clark, 2010);

- organize an interoperable workflow to make the results comparable in light of the application of the "falsification principle" and "self-correcting" supported by Karl Raimund Popper (1935) and the "Document on Authenticity" issued by UNESCO for digital modelling;

- discuss its accessibility on a theoretical-philosophical (Landi 1991, pp. 565-574) and practical-operational (McLuhan 1967) level, to enter the current debate and discuss the repercussions deriving from the declination of a renewed information paradigm within of a data sharing environment (CDE) (Jordán et al., 2020).

\footnotetext{
${ }^{1}$ http://www.londoncharter.org
}

\section{MATERIALS AND METHODS}

The artefact hailing from Rome $^{2}$, is conserved in the Archaeological Museum of Perugia (Cante, Manconi 2004, p.63). It is a rectangular marble slab (circa $58 \times 82 \mathrm{~cm}$ ), in excellence condition to be studied with meticulous care (Figure $1)$.

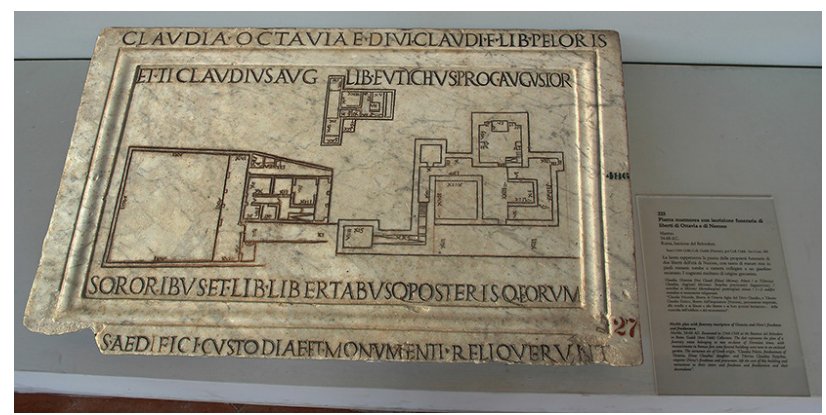

Figure 1. Marble plan with funerary inscription of freedmen of Octavia and Nero 54-68 AD Coll. Gaddi Coll. Oddi, Inv. Com. 486. Exhibit n.45 (CIL VI, 2, 9015).

The document is composed by an engraving of the marble slab divided in three horizontal sections, variously proportioned and meticulously dimensioned in roman feet:

1. the ground floor of a funerary monument whit an open triclinio;

2. the planimetry of a ground floor of a rustic villa with a garden behind;

\footnotetext{
2 "Bastioni del Belvedere 1544-1548, first of all coll. Gaddiorum (Firenze) then coll. Oddios in museo
} univeritatis" 
3. the plant of a mezzanine floor of a hypothetic residence of the housekeeper.

The epigraph that extends along two longitudinal lines at the top and bottom of the slab clarifies that this slab is a donation for Claudia Peloris, freedwoman of Claudia Octavia, daughter of the emperor Claudio and of Valeria Messalina ${ }^{3}$. This information permits di determine unambiguously the date of creation of the engraving between the 52 and the $63 \mathrm{AD}$.

Few, erudite texts consider the engravings on the slab of Perugia as emblem of the mathematical rationality of the roman builders during the imperial period. Heinrich Jordan was the first scholar who examined in deepen the slab. The Roman topography expert underlines the merits and limitations of the graphic signs carved on the slab (Jordan, 1874, 1878).

The rooms are meticulously quoted in Roman figures. Using the "foot" (Pes, in Latin), generally accepted as 16/28 of the cubit of Nippur, that is equivalent, to 0.29574 meters. The "S", visible at the end of some digits, is the representation of "Span", "Spanna" (half cubit, 9 inches, $22.86 \mathrm{~cm}$ ) or "Semis" (half foot, about $15 \mathrm{~cm}$ ), confirm the centesimal precision of the dimensioning of the rooms in plan compatible with a relief drawing of the existing building scale, rather than with a project drawing.

\begin{tabular}{|c|c|c|c|c|}
\hline $\begin{array}{l}\text { I level } \\
\mathrm{N} \text {. in the } \\
\text { plan }\end{array}$ & $\begin{array}{l}\text { Lower floor } \\
\text { hypothetic } \\
\text { function }\end{array}$ & $\begin{array}{l}\text { Dimensions in } \\
\text { roman foot } \\
\text { Width-length }\end{array}$ & $\begin{array}{l}\text { Measurements } \\
\text { in cm } \\
\text { width-length }\end{array}$ & $\begin{array}{l}\text { Measurements } \\
\text { taken from } \\
\text { geometry }\end{array}$ \\
\hline (01) & anterior porch & $X V I-L X X$ & $474-2075$ & $474-2419$ \\
\hline (02) & room $n 2$ & V-VIS & $148-193$ & $148-193$ \\
\hline (03) & room $n 3$ & $\mathrm{VI}-(-)$ & $178-(-)$ & $178-181$ \\
\hline (04) & room $n 4$ & $X X-X I$ & $593-326$ & $593-326$ \\
\hline (05) & room $n 5$ & XII-XI & $356-326$ & $356-326$ \\
\hline (06) & room $n 6$ & XIII-VIIS & $385-222$ & $385-466$ \\
\hline (07) & corridor & $(-)-V$ & $(-)-148$ & $782-148$ \\
\hline (08) & room $n 8$ & $x-$ VIII & $296-237$ & $296-237$ \\
\hline (09) & room $n 9$ & $I X-V I I I$ & $267-237$ & $267-237$ \\
\hline (10) & atrium & $(-)$ & $(-)$ & $313-458$ \\
\hline (11) & staircase & $(-)$ & $(-)$ & $531-170$ \\
\hline (12) & corridor & $(-)-V$ & $(-)-148$ & $531-148$ \\
\hline (13) & posterior porch & $(-)$ & $(-)$ & $296-857$ \\
\hline (14) & stable & VI- (-) & $178-(-)$ & $178-281$ \\
\hline (15) & $\begin{array}{l}\text { vegetable } \\
\text { garden }\end{array}$ & LXV-LXX & $1926-2075$ & $2390-2419$ \\
\hline (16) & access road & $(-)-X X S$ & $(-)-607$ & $1890-607$ \\
\hline $\begin{array}{l}\text { II level } \\
\mathrm{N} \text {. in } \\
\text { the plan }\end{array}$ & $\begin{array}{l}\text { Lower floor } \\
\text { hypothetic } \\
\text { function }\end{array}$ & $\begin{array}{l}\text { Dimensions in } \\
\text { roman foot } \\
\text { Width-length }\end{array}$ & $\begin{array}{l}\text { Measurements } \\
\text { in } \mathrm{cm} \\
\text { Width-length }\end{array}$ & $\begin{array}{l}\text { Measurements } \\
\text { taken from } \\
\text { geometry }\end{array}$ \\
\hline (01) & anteriorporch & XS- (?) & $311(\dot{d})$ & $401-495$ \\
\hline (02) & room $n 2$ & (?) $-X X$ & $474-563$ & $636-593$ \\
\hline (03) & room $n 3$ & $\mathrm{XI}$ VII & $326-207$ & $296-207$ \\
\hline (04) & room $n 4$ & $\mid \mathrm{X}-\mathrm{VII}$ & $267-207$ & $267-207$ \\
\hline (05) & atrium & $X X X-(?)$ & 889 & $889-1005$ \\
\hline (06) & posterior porch & $(?)-(-)$ & - & $291-1005$ \\
\hline
\end{tabular}

Table 1. Edificium custodiae. Numerical comparison between the data quoted in figures (Roman feet) transposed in $\mathrm{cm}$ and measured in the marble reduction scale. The distribution of spaces refers to the study by Rodriquez Almeida, 2002, fig. 13, chap. IV.

\subsection{Analysis of the measurements: sources and documents}

Based on the direct comparison between geometric configurations and real measurements, Guglielmo Gatti (Gatti,
1974, p.33) estimated the reduction scale of $1: 83$ for (the sepulchral temple with an underground crypt and outdoor triclino. This proportional ratio is halved in the adjacent iconography: the ground floor of the villa is engraved on a scale of 1:140; the plan of the custodian's accommodation is further reduced on a scale of 1:230 (Rodríguez-Almeida, 2002). These differences in the scalar ratios are not surprising, considering that the importance of each building is based more on its representational idea than its use. The position of the upper floor gains some doubt, since its proportions compared to the other plans are smaller, almost as if was added at the end as an extra.

Regarding the dissymmetry between the indicated and calculated heights, they were duly detected and noted (Tab.1) in order to vectorize the linear extensions of the walls in one metric scale by adopting a mean value derived from the comparison between the dimensions and the graphical readings. The use of a grid derived from the thickness of the walls (Figures 2-3) in which the module-measurement of Vitruvian memory relates harmoniously the position of the single portions referring them to the different parts (De Fusco, 1968), guided the subsequent analyses.

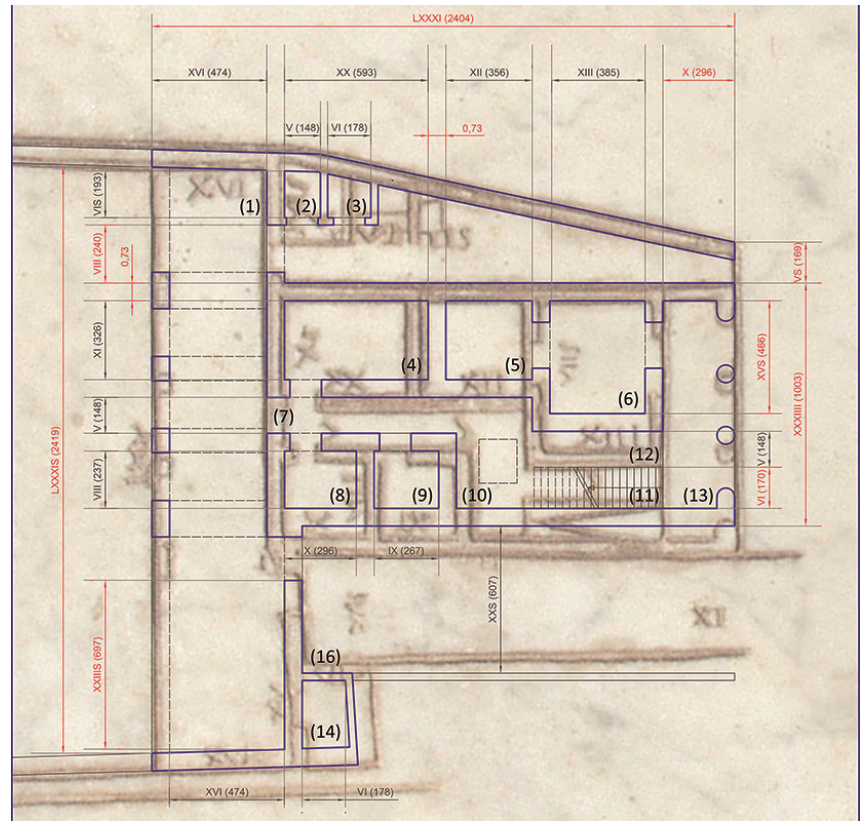

Figure 2. Edificium custodiae. Graphic comparison between the data obtained by superimposing the lines engraved on the marble and the quotas in Roman figures for the ground floor (see Tab.1).

\subsection{Distribution and functionality of the spaces}

According to clear criteria and immediate communication, the iconographies visualize the supporting framework of the artifacts. In this sense, the iconic clarity of the conventions and symbols engraved in the first century slab is astounding. These anticipate almost unchanged the conventions that make the "Forma Urbis Marmorea Severiana" (III century AD) the cartographic document par excellence (Carettoni et al., 1960).

${ }^{3}$ Claudia, Octaviae divi Claudi f(iliae) lib(erta) Peloris/ et Ti(berius) Claudius Aug(usti) lib(ertus) Eutychus, proc(urator) Augustor(um), / sororibus et lib(ertis) libertabusq(ue) posterisq(ue) eorum/ /form]as aedifici custodiae et monumenti reliquerunt. 


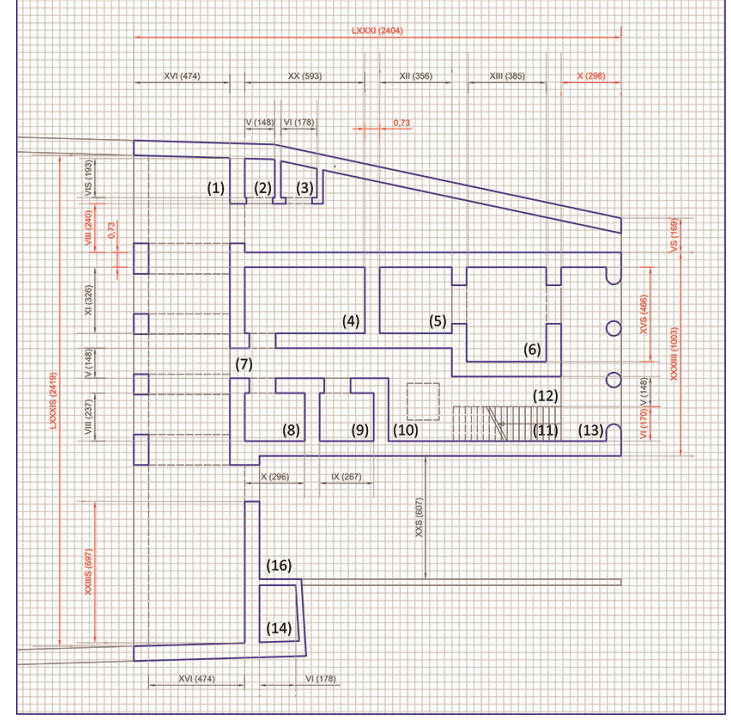

Figure 3. Edificium custodiae. Use of a grid derived from the thickness of the walls. The measure-module measures the parts. The numbers of the rooms refer to the functional distribution referred to in Tab.1.

The walls are traced with a double line, as if to indicate the consistent thickness of the plaster that covers the rows of bricks. Clearly visible is the thickness of the walls cut at a useful height to show the gaps in the light compartments. In the views from above, however, the roofs are sculpted in their dimensions: this is verified by observing the iconography of the mezzanine floor, and in more detail that of the underground body in the plan of the monumental building. Following the advices of Vitruvius, the orientation of the temple will certainly have taken into account the apparent path of the sun (Bodel, 2017, pp.226-228). In the aedificium custodiae, where the functional needs are dominant with respect to the ones in the monumental buildings, the builder kept into mind the microclimatic needs imposed by the habitability of the rooms, in that period without fixtures (Vitrv., De Arch., I, 1). Hence, the distribution of the rooms is articulated around the path that connects the anterior courtyard to the posterior one; the path is identified by a ramp, perhaps equipped with a staircase, indicated in the plan, as is still the case today.

Entering into the merits of the distributive hypotheses formulated by Emilio Rodriquez Almeida (Rodriquez Almeida, 2002, fig.13, chap. IV) the Romans did not know the use of the fireplace, or the hood or the flue, visible in the Italian architecture from the thirteenth century. This is confirmed by the etymology of the term Atrius, "dark", because of the dust that darkened the walls where the water was formerly collected and at the same time the wood for cooking was burned. The smoke found its main outlet in the aperture of the roof, which came from that visible on the top of the pre and protohistoric huts. Hence the need to postulate a well of air and light on the roof at the vertical connecting ramp-staircase and the room behind it where, according to Rodriquez, food was smoked (on the second level) or cooked on the first level.

\section{RECONSTRUCTIVE HYPOTHESIS: AIMS AND} METHODS

The engraving excludes any type of information on the elevations, the elements than more than others imprint onto the visive memory of the visitors. These are necessary data for the elaboration of a collaborative environment useful to learn and comprehend the background to explore the functionality of a dedicated platform with the aid of multimedia interface (visual, auditive and tactile). Using apps and open-source software, linear or map indexes guide to orient a personalized experience (MR, Mixed reality). The opportunity to actualise issues (Bolter, Grusin, 1999) in harmony with the international definition of "Heritage", places the digital reconstructions at the centre of cognitive, planning and communication strategies. To proceed with a scientific method, it is necessary to premise in a transparent way the sources on which the reconstruction is based, along with the declaration of the choices that led to the different readings-interpretations and on which the applicative procedures are based.

\subsection{Procedural and technical methodologies}

On the operational level, it seemed useful to discern the reconstruction of the monumental building from the service one for the caretaker.

a) aedificium monumentalis. Christian Carl Friedrich Hülsen made an axonometric projection sketch of the monumental building (Hülsen, Friedrich, 1890, p.53) supposing the aspect of the facade, repeating the style of the triumphal arches built in the Augustan and Giulio Claudia era (Figure 4a). As a reference for the reconstruction, it was used also the Archaeological Museum on the isle of Malta (Figure 4b), built around archaeological remains of the I century AD. Taken together, the sources make the morphological choices of the monumental building scientifically plausible. These are inductively verifiable in the light of the "Document on Authenticity" (Unesco 1994) and the statements on the Safeguarding of the Intangible Cultural Heritage (Unesco, 2003 and 2009). On the other hand, the rebuilt of the villa is more subjective, due to the lack of archival data. The declaration of the sources permits on the other hand to value the historic reliability of the reconstruction (Wijesuriya, 2008, p.65).

The basis is the data derived from the analysis of the marble slab. The reference grid deduced from the measurement module, if overturned in elevation on the vertical plane (Figure 5), covers the principles to the elaboration of the elevationssections (Orthographia). The alignments were then compared with the proportions of the axonometric sketch hypothesised by Heinrich Jordan.

b) aedificium custodiae. It is mandatory to remember that in addition to the geometries and arithmetic relationships, the material extension of the architecture is measured with history and technology. The 3D reconstruction considered the Roman construction technique. The virtualizations of a similar era, freely drawn from the shared network (internet), were indeed helpful. Here lays the opportunity to use software that can digitally build the choices made.

In order to proceed quickly with the construction of the threedimensional model from which to derive the two-dimensional graphics (Eastman et al., 1975), the floor plan of the monumental complex made in CAD was developed into the Bim software Revit by Autodesk, a powerful tool for the planning of new buildings, providing a shared work environment during all the phases of the project. (Lu et al. 2016; Woodward, Heesom, 2021; Fai et al, 2012).

Its characteristics therefore are appropriate to complex and rich approaches to the potential inherent in information models (Garagnani, 2019; Arayci et al., 2011).

For these reasons, a model has been proposed that includes the following phases (Bianchini et al., 2021):

- classification of construction elements (semantization);

extraction of geometries with the direct method (segmentation); 
- modelling of geometric attributes (2D and 3D);

- development of components according to a declared level of information;

- taxonomic organisation of graphic circumstances within a shared and interoperable workflow.

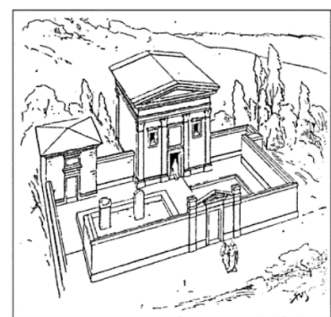

a building: a) Hypothesis by Christian Carl Friedrich Hülsen presented in an axonometric sketch; b) Malta, Domus Romana. Reconstruction around the archaeological findings of the temple with an underground crypt and outdoor triclino (I century).

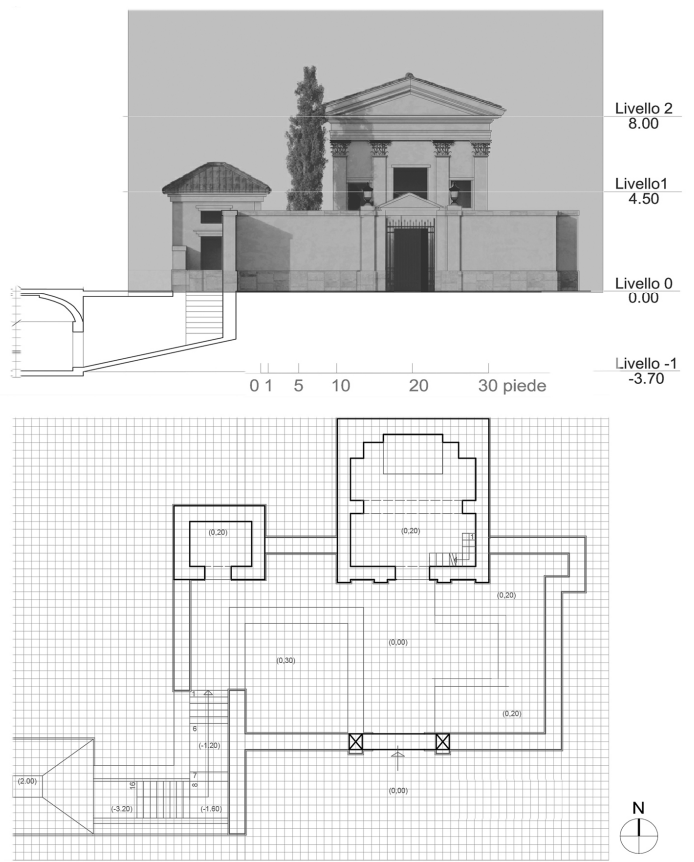

a

Figure 5a. Aedificium monumentalis (a). Use of the grid to compare the proportions of the southern elevation of the temple with the proportions obtained by studying the iconographic documents

\subsection{Executive choices}

A first information model has been created, based on both the geometric (LOD-detail) and the informative descriptors (LOIInformation). The extraction of the components with the direct method allows the contextual association of families of technologically determined types stored in dedicated system instructions (Garagnani, 2019, p.47-73). However, since this is a first-century construction, there are no archival data that can support the $3 \mathrm{D}$ reconstruction ${ }^{4}$. It is possible to proceed correctly by linking technical data sheets adequate to the information need (Level of Information Needed) to the

4 https://www.ingenio-web.it/18667-sistema-dei-lod-italianouni-11337-4-2017 geometric detail with qualitative and quantitative 3D LOG attributes.

The formal structure of the geometric model is conceptually linked to information sheets (LOI). In fact, European and therefore Italian legislation discerns the level of detail by distinguishing geometric representations/virtualizations from non-geometric representations/virtualizations (Figure 6) (Baker, 2012; Maiezza, 2019). This is in an attempt to clarify the controversial level of detail referred to in previous UK and US LoD regulations as LoD A refers to symbolic object, LoD B to generic object, LoD C to defined object, LoD D to detailed subject, LoD E to specific object, LoD F to executed object and LoD G to object updated (Jallow et al., 2019).

A first Level of Information Needed (the construction of an ad hoc archive is in progress), was obtained by identifying objectcomponents such:

a. Vertical structures. The "Opus Testaceum" in the first century was placed side by side with other construction techniques, allowing the bricks to be broken along the lines generated raw (Luglio 1957, Plate CLXI-CLXXXIV). This type of wall is appropriate for receiving and discharging the loads coming from the arches supporting the cewilings of the ground floor of the villas (Adam, 2017). Only in the more modest houses were the flat floors made of wood.

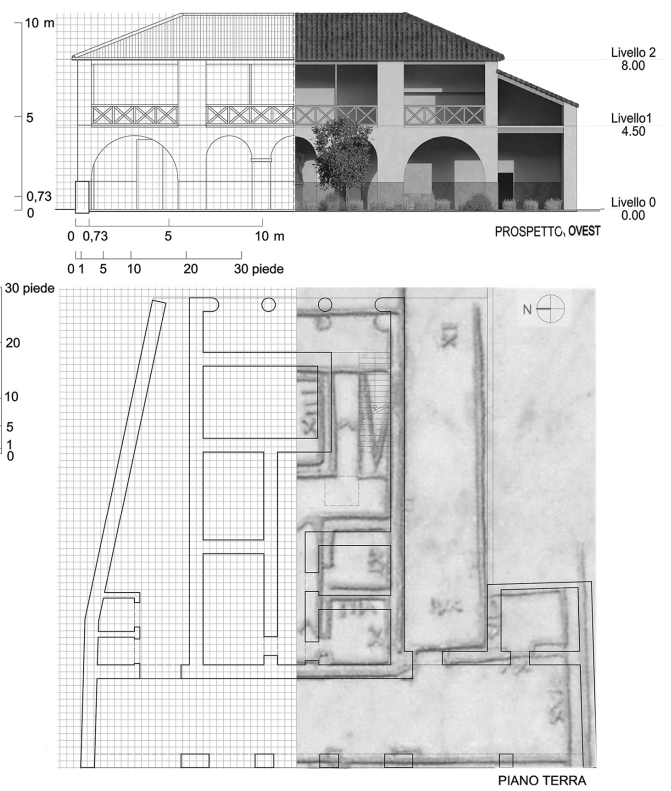

Figure 6b. Aedificium custodiae (b). Use of the grid to compare the proportions of the west elevation with the adjacent ones of the temple and with the reconstructions of rustic villas.

b. Horizontal structures. The use of beams did not involve any or a very limited horizontal force on the straight leg but it had to be considered that the openings could not exceed 4 feet. This problem could be avoided with the use of arches that allowed to deflect part of the load; hence the light compartments were wider (Choisy, 1904, p.503-505). The wooden rib shaped using circular arches (El-Naggar, 1999; Heisel, 1991) allowed to create the structure of the ashlars used for the construction of a "simple" vault, e.g., the barrel vault and, when necessary, a cross vault (Docci, Migliari, 1992, p. 455)

c. Cover structures. The roofs were usually constructed with double or quadruple pitches. For this reason, rectangular beams and props were used or, alternatively, boards of thickness between 5 and $10 \mathrm{~cm}$ on which the roof tiles were placed. 


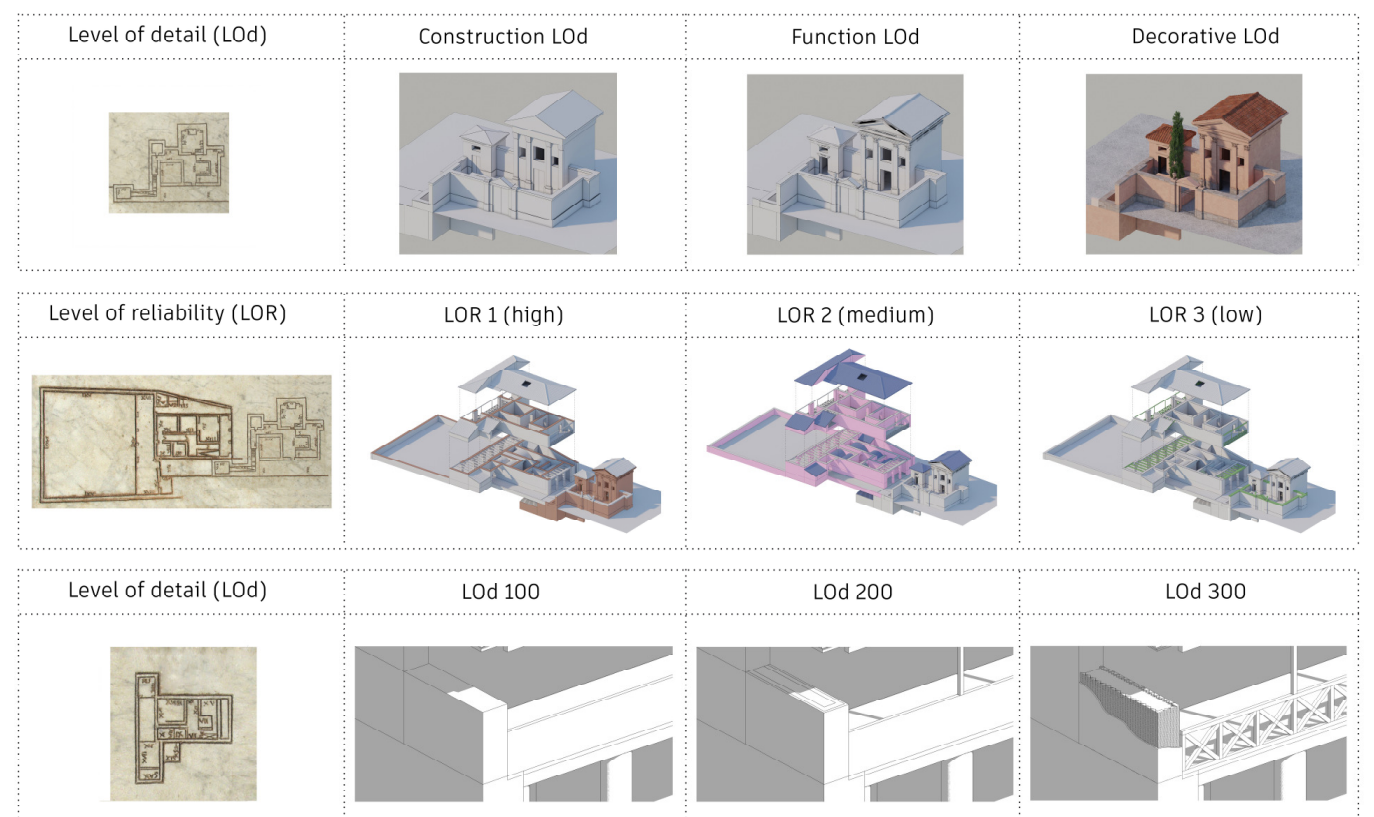

Figure 7. The differentiation in LoD referring to the functionality, the graphical and geometrical details in the models and the distinction of three different Level of Reliability referring to the process used to reconstruct the final model: high reliability refers to the reconstruction of the plan based on the engravings and the mathematical calculation, medium refers to the vertical structures reconstructed on bibliographical data, low consists on the accessories elements as parapets, for which no data where found.

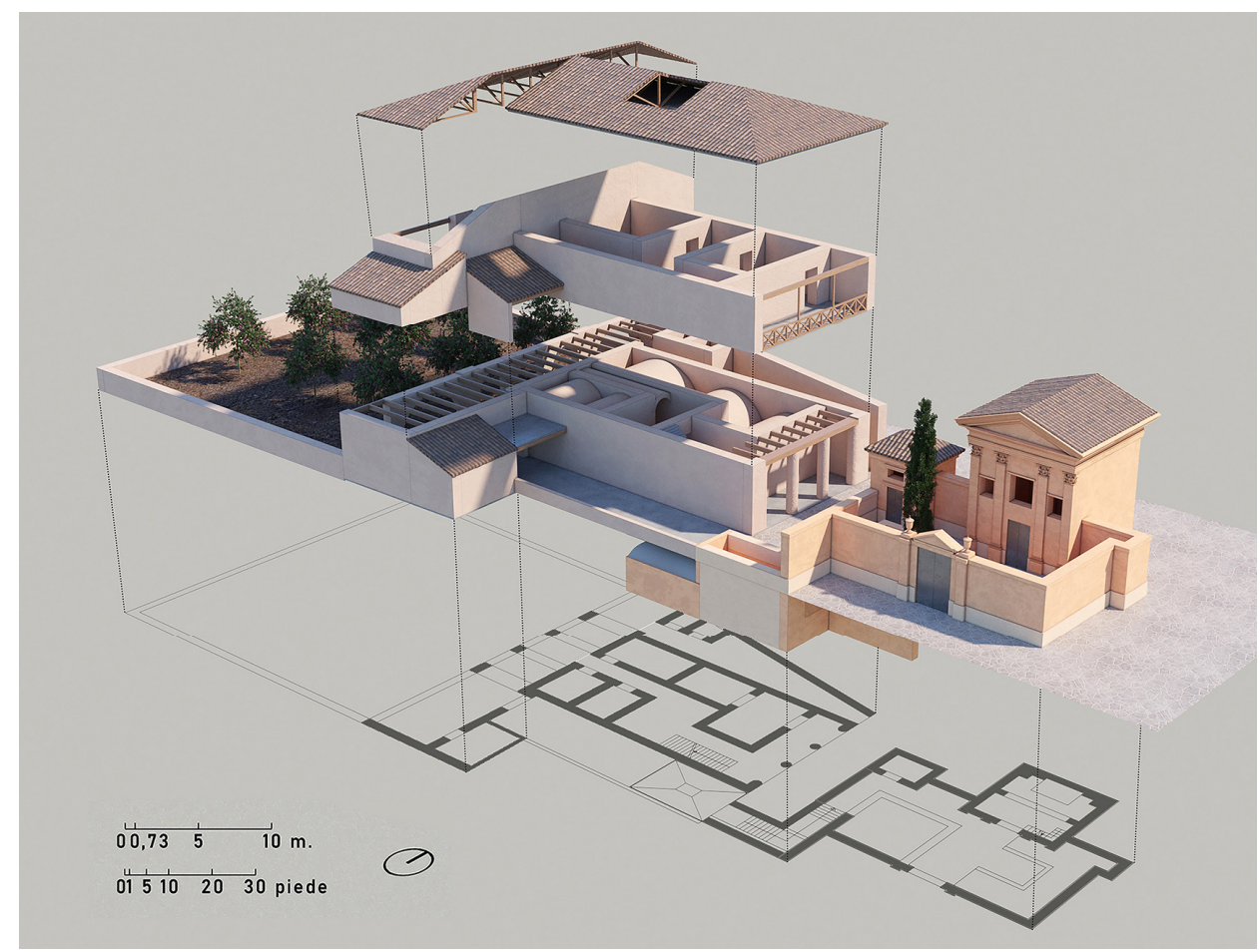

Figure 8. View of the 3D model referred to in graphic virtualizations visible in https://sketchfab.com/3d-models/table-of-perugia89df393019e246ea9f090a66f691ee35 


\section{CONCLUSIONS}

In recent decades, two paths have been taken to make scientific research dialoguing with the production of data (De Luca, 2020a). These, in essence, are attributable to the strong modelling and to the contextual research on the ontological transmission of data articulated around the interdependence of space, time and form.

This paper discusses the 3D reconstruction (Figure 7) phases methodologically based on sources and on the transparency of the pipeline (Figure 8-9-10). It is common practice to share the model in digital repositories that the organization of a workflow on the web platform makes shared and interoperable. This is an opportunity to reflect and experiment new methods of support (complete and/or integrated) for the dissemination of the "inherited architectural heritage" (Brusaporci et al., 2020).
For this purpose, the organization of a portal to which an enlarged and differently enabled user can access is in progress (Figure 8). The ultimate goal is the design of a digital ecosystem compliant with the identified semantic needs (De Luca, 2020b). This system will be useful for developing a cultural, intelligible and shared vision of the Imperial era. In this context, the socalled "slab of Perugia" is a testimony of fundamental importance for the history of the survey and, in actuality, for the debate on the accessibility of architectural studies as structural ensembles capable of "remedying" contents and meanings for educational purposes. By reducing the distance between inherited goods and the "consumers" of culture it will be possible to advance in knowledge and at the same time raise awareness among the users necessary for protection and enhancement policies.
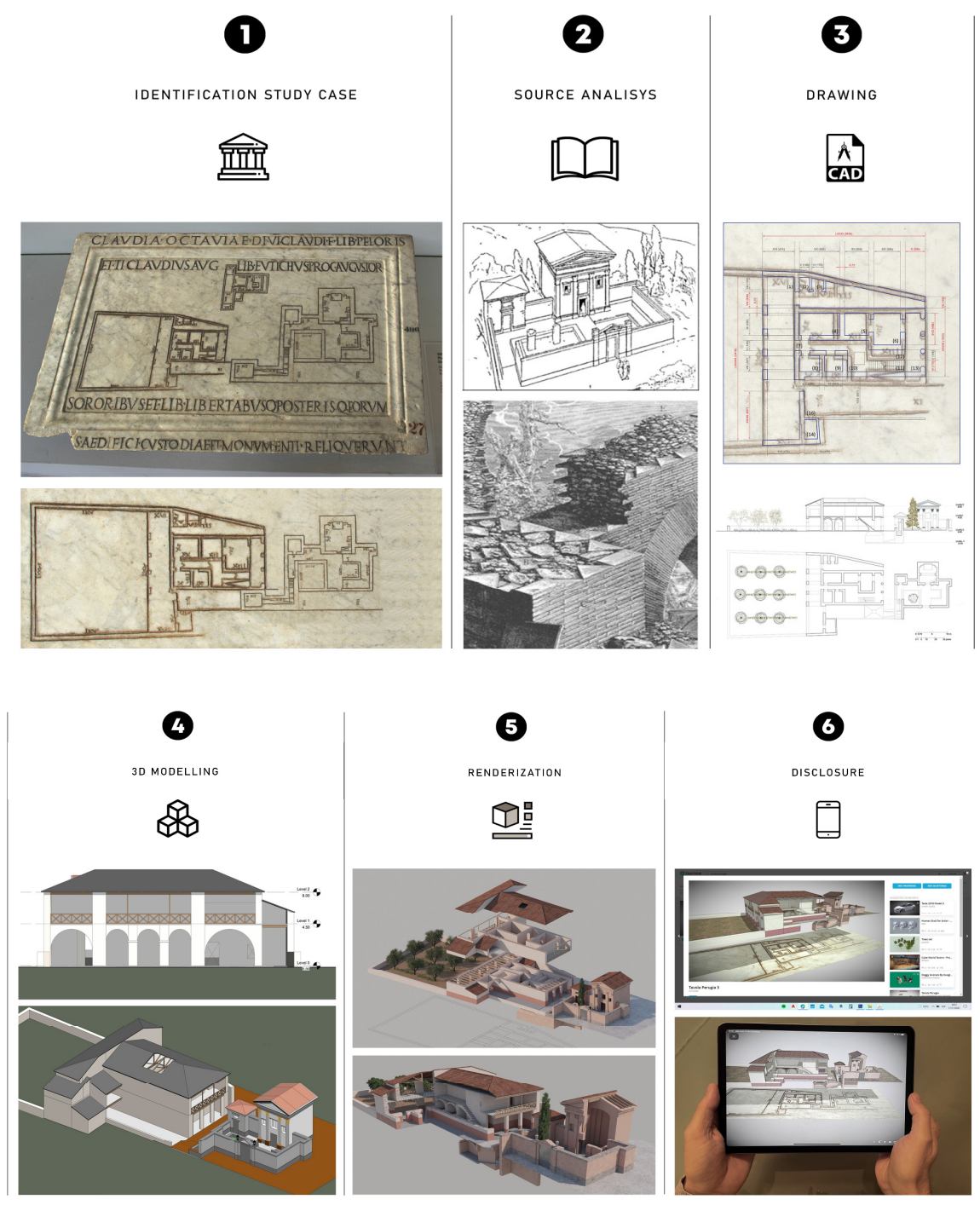

Figure 9. The process that, starting from the analysis of the artefact led to the sharing of the 3D final model. 


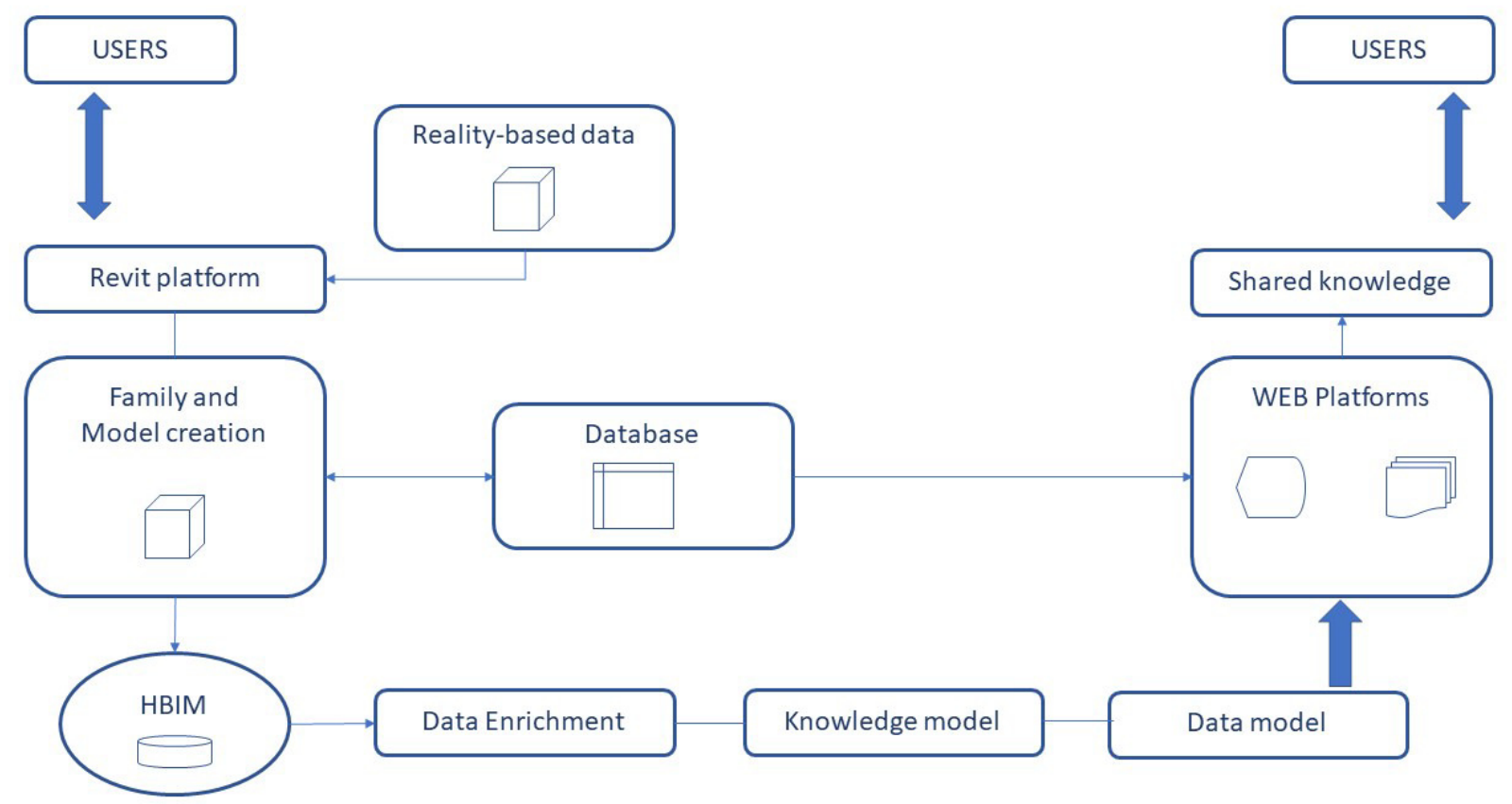

Figure 10. The schema of the process

\section{REFERENCES}

Adam, J.P., 2017. L'arte di costruire presso i Romani Materiali e tecniche. Milano: Longanesi

Arayici, Y., Coates, P., Koskela, L., Kagioglou, M., Usher, C. and O'Reilly, K., 2011. BIM adoption and implementation for architectural practices, Structural Survey, Vol. 29 No. 1, pp. 725. https://doi.org/10.1108/02630801111118377

Baker, D., 2012. Defining Paradata in Heritage Visualization. In Paradata and Transparency in Virtual Heritage; BentkowskaKafel, A., Denard, H., Baker, D., Eds.; Routledge: London, UK, pp. 238-251.

Barratt, R.P., 2018. Defining a Methodology for 3D Approximations in Archaeology: The Issue with Alternative Models. In Proceedings of the 23rd International Conference on Cultural Heritage and New Technologies, Vienna, Austria, 1215 November 2018; p. 12.

Bentkowska-kaFel A., Denard, H. (Eds.), 2012. Paradata and Transparency in Virtual Heritage, Routledge

Bianchini, C., Attenni, M., Potestà, G., Regenerative Design Tools for the Existing City: HBIM Potentials, Rethinking Sustainability Towards a Regenerative Economy, 23-43

Bodel, J., 2017. Roman Tomb Gardens. In: Jashemski, W., Gleason, K., Hartswick, K. \& Malek, A. (Eds.), Gardens of the Roman Empire, cap. 8, Cambridge University Press.

Bolter, J., D., Grusin, R., 1999. Remediation - Understanding New Media. Cambridge, MA: MIT Press.

Brusaporci, S., Maiezza, P., Tata, A., 2020. Toward Smart Heritage: Cultural Challenges in Digital Built Heritage In book: Applying Innovative Technologies in Heritage Science January 2020 DOI: 10.4018/978-1-7998-2871-6.ch013
Cante, M., Manconi, D., Cipollone M. (Eds.), 2004. Perugia. Museo Archologico Nazionale dell'Umbria. Chiostro Maggiore e lapidario. Perugia: Volumnia Editrice

Carettoni, G. Colini, Antonio Maria; Cozza, Lucos; Gatti, Guglielmo Eds., 1960. La pianta marmorea di Roma antica. Forma urbis Romae, 2 voll., Roma.

Choisy, A., 1904. L'art de bâtir chez les égyptiens. Paris: E. Rouveyre

Clark, J.T. 2010. The Fallacy of Reconstruction. In CyberArchaeology; Forte, M., Ed.; Archeopress: Oxford, UK, pp. 6373.

De Fusco, R., 1968. Il codice dell'architettura antologia di trattatisti. Napoli: E. S. I.

De Luca, L., 2020a. Towards the Semantic-aware 3D Digitisation of Architectural Heritage:The "Notre-Dame de Paris" Digital Twin Project, SUMAC'20: Proceedings of the 2nd Workshop on Structuring and Understanding of Multimedia heritAge ContentsOctober 2020 pp 3-4 https://doi.org/10.1145/3423323.3423415

De Luca, L., 2020b. A digital ecosystem to document, in space and time, the restoration of Notre-Dame de Paris, https://www.canal-u.tv/chaines/mshvaldeloire/fair-heritage1718-juin-2020/dr-livio-de-luca-a-digital-ecosystem-todocument

Denar D. H., 2012. A new introduction to The London Charter, in Paradata and Transparence in Virtual Heritage, Routledge

Docci, M., Migliari, R., 1992. Scienza della rappresentazione. Roma: Nuova Italia scientifica

El-Naggar, S., 1999. Les voûtes dans l'architecture de l'Égypte ancienne. Le Caire: Institut Français d'Archéologie Orientale. 
Eastman, C.M. (Ed.), 2011. BIM handbook: a guide to building information modeling for owners, managers, designers, engineers, and contractors. New Jork: Wiley, Hoboken

Fai, S.; Graham, K.; Duckworth, T.; Wood, N.; Attar, R., 2012. Building information modelling and heritage documentation. In Proceedings of the 18th International Conference on Virtual Systems and Multimedia, Milan, Italy, 2-5 September 2012.

Garagnani, S., 2019. Il BIM dell'esistente. Verso la digitalizzazione evoluta del patrimonio costruito, in BIM - Oggi - Italia. Padova: librriauniversitaria.it, pp.47-71

Gatti, G.,1974. La pianta marmorea severiana, Roma, no, in ID. Topografia ed edilizia di Roma antica. Ristampa anastatica di tutti gli articoli di Guglielmo Gatti pubblicati dal 1934 al 1979. Roma: "L'Erma" di Bretschneider

Heisel, Joachim P., 1991. Antike Bauzeichnungen. Darmstadt: Wissenschaftliche Buchgesellschaft.

Hugh, D., 2012. A new introduction to The London Charter. In Paradata and Transparency in Virtual Heritage; Routledge: Abingdon, UK, pp. 57-71.

Hülsen, C., Friedrich, C., 1890. Piante icnografiche incise in marmo. pp. 46-63. In «RM», 5 (1890), CIL VI, 2.9015 e 4.29847; PM, pp. 208-210.

Jallow, H., Renukappa, S., Suresh, S., Alneyadi, A., 2019. Implementing a BIM Collaborative Workflow in The UK Infrastructure Sector. In Proceedings of the 2019 3rd International Conference on Information System and Data Mining - ICISDM 2019, Houston, TX, USA, pp. 103-108.

Jordan, H., Hülsen, C.,1874. Forma Urbis regionum XIIII, Berolini

Jordan, H., Hülsen, C.,1878. Topographie der Stadt Rom im Alterthum, Berlin: Weidmannsche Buchhandlung

Jordán Palomar, I., García Valldecabres, J.L., Tzortzopoulos, P., Pellicer, E., 2020. An online platform to unify and synchronise heritage architecture information. Autom. Constr., 110, 103008. ISSN 0926-5805. https://doi.org/10.1016/j.autcon.2019.103008.

Landi, L., 1991. Cassirer, Husserl e l'ermeneutica. Riv. di Stor. Della Filos., 565-574.
Lu, Q., Won, J., Cheng, J.C.P., 2016. A financial decision making framework for construction projects based on 5D Building Information Modeling (BIM). International Journal of Project Management (34), 3-21

Luglio, G., 1957. La tecnica edilizia romana con particolare riguardo a Roma e Lazio (Tav. CLXI-CLXXXIV). Ed. cons. Ristampa 2016

Maiezza P., 2019. Ricostruendo in Digitale. Metodi e modelli per i beni architettonici. Alghero:Publica

McLuhan, M., 1967. Understanding Media. The Extension of Man; trad. it. Gli strumenti del comunicare: Press, Cambridge. Massachusetts

Popper, K., 1935. The Logic of Scientific Discovery. Vienna: by Verlag von Julius Springer

Rodríguez-Almeida E., 2002. Le forme marmoree di Roma di tradizione augustea. In: «Collection de l'École française de Rome», cap IV

Tacitus, P. G. C. (114-120 d.C. c.a). Annales, Ab excessu Divi Augusti libri, libro XIV 60-64.

UNESCO, 1994. Nara Document on Authenticity. Retrieved on November 2016.

UNESCO, 2003. Convention for the Safeguarding of Intangible Cultural Heritage.

UNESCO, 2009. World Heritage Cultural Landscape.

Vitruvio, P.M. (19 d.C.). De Architectura. Ed. cons. I Dieci libri dell'architettura di M. Vitruvio tradotti et commentati da monsignor Barbaro, con i disegni di Andrea Palladio Venezia 1556.

Wijesuriya G., Thompson J., \& Young, C. (2006). Manuale delle risorse Gestire Il Patrimonio Mondiale Culturale. International d'Études pour la Conservation et la Restauration des Biens Culturels (ICCROM). Paris: UNESCO 2019. Serie World Heritage Resource Manual https://www.icomositalia.com/carte-e-testi-dottrinali;

Woodward, A. Heesom, D., 2021, Implementing HBIM on conservation heritage projects: Lessons from renovation case studies. Int. J. Build. Pathol. Adapt., 39, 96-114. https://doi.org/10.1108/IJBPA-06-2019-0054. 